\title{
Dietary protein: a trigger of insulin-dependent diabetes in the BB rat?
}

\author{
R. B. Elliott and J. M. Martin \\ Research Institute, The Hospital for Sick Children, Toronto, Canada
}

\begin{abstract}
Summary. Animals from a colony of spontaneously diabetic insulin-dependent BB rats were fed from weaning with semisynthetic diets in which natural proteins were replaced by $l$-amino acids with or without the addition of either milk or wheat proteins. The normal $50 \%$ incidence of diabetes in the colony was reduced to $15 \%$ in rats fed the basic semi-synthetic
\end{abstract}

diet, while it was $35 \%$ and $52 \%$ when supplemented with gluten or milk, respectively. Thus, dietary factors might precipitate the expression of the disease.

Key words: Rat, pathogenesis, insulin-dependent diabetes, dietary proteins, milk proteins, wheat proteins.
Rats of the non-obese spontaneously diabetic BB Wistar strain commonly develop severe diabetes between the ages of 40-140 days with a peak incidence at about 90 days. With an inbreeding programme the overall incidence is about $50 \%$ in the colony offspring. A strong genetic component is apparent [1].

An environmental precipitating influence operating on a basis of genetic susceptibility has been suggested [1], but the nature of such a factor has not been elucidated. Attempts to demonstrate a viral infection as the precipitating event have not met with success.

In this communication, we describe experiments aimed at establishing whether one dietary component, intact protein, is necessary for the evolution of the disease in these rats. These experiments were prompted by anecdotal reports suggesting low incidence of insulindependent diabetes in people from countries with a low protein intake, with emergence of the disease on adopting a high protein intake. For example, childhood diabetes is considered to be rare among ethnic Chinese in Singapore, whereas in Chinese living in Australia it is probably as common as in the Caucasoid community. Similarly, diabetes has never been reported in Polynesian children in Western Samoa, whereas the prevalence in recent Samoan immigrants in Auckland, New Zealand is approximately $1 / 2000$ children aged 15 years (R. B. Elliott, personal observation).

\section{Materials and methods}

Weaning rats from seven litters bred in the hybrid BB colony in Toronto were reduced to nine per litter; three animals from each litter were distributed randomly into three groups (to a total of 21 rats in each), and housed three or less to a cage. Starting at weaning, the animals received one of three experimental diets: the first contained all essential nutrients, but the protein was replaced with $l$-amino acids (group 1) [2]. The second contained, in addition, 1\% by weight of gliadin, the solvent-extracted protein from gluten (group 2). The third contained instead of gliadin, a 1\% (by weight) addition of skim milk powder (group 3). A chow-fed group derived from different litters of the same colony, but of common parentage with the experimental rats, was also studied for control purposes. All diets were purchased in pelleted form from Nutritional Biochemicals, Cleveland, Ohio, USA. (Table 1). The animals were fed ad libitum, weighed thrice weekly and their urine tested for glucose at the same time. When diabetes supervened (as recognized by persistent 3-4 + glycosuria, nonfasting blood glucose above $8.9 \mathrm{mmol} / 1$ and usually weight loss), the animals were killed and the pancreas removed and fixed in Bouin's solution (haematoxylin-eosin, and aldehyde-thionine stains) for subsequent histology which provided the definitive confirmation of the diagnosis.

All non-diabetic animals were killed at 133 days of age. In three of these, we found hyperglycaemia $(10.0,11.1$ and $13.0 \mathrm{mmol} / \mathrm{l})$ with histological signs of insulitis in two of them. Therefore, these two were considered diabetic and were tabulated accordingly. The results were analysed statistically by either the Student or the Fisher exact tests.

\section{Results}

All three experimental groups of animals, when nondiabetic, grew at identical rates (Fig. 1) which were significantly lower (except for female rats older than 100 days) than the chow-fed group.

The incidence of diabetes, as diagnosed initially by glycosuria, is shown for all the groups in Table 2 with age at onset and sex. Clearly, the addition of skim milk powder to the diet resulted in an incidence of diabetes $(52 \%)$ comparable to that found in our colony and in others when fed regular rat chow. The incidence in the 
Table 1.

a) Overall composition of diets ( $\%$ by weight)

\begin{tabular}{lllll}
\hline Ingredients & Group 1 & Group 2 & Group 3 & Control \\
\hline $\begin{array}{l}\text { Semi-synthetic base } \\
\quad \text { (excluding amino-acids) }\end{array}$ & 80.9 & 80.4 & 80.4 & - \\
l-amino acids & 19.1 & 18.6 & 18.6 & - \\
Gliadin & - & 1.0 & - & - \\
Skim milk powder & - & - & 1.0 & - \\
Purina laboratory chow & - & - & - & 100
\end{tabular}

b) Detailed composition of dietary ingredients (\% by weight)

\begin{tabular}{|c|c|c|c|c|}
\hline & $\begin{array}{l}\text { Semi-synthetic } \\
\text { base }\end{array}$ & Gliadin & $\begin{array}{l}\text { Skim milk } \\
\text { powder }\end{array}$ & Chow \\
\hline Carbohydrates & 79.4 & - & 52.0 & 50.0 \\
\hline Fat & 12.4 & - & 0.8 & 5.0 \\
\hline Protein & - & 100 & 36.2 & 23.0 \\
\hline Salt mixture & 6.2 & - & - & - \\
\hline Vitamins & 0.6 & - & - & 0.02 \\
\hline Choline chloride & 1.5 & - & - & 1.3 \\
\hline Fibre & - & - & - & 5.2 \\
\hline Ash & - & - & 7.9 & 7.3 \\
\hline Moisture & - & - & 3.1 & 10.0 \\
\hline \multicolumn{5}{|c|}{ l-amino acids: (as hydrochlorides) } \\
\hline Arg & 5.6 & & & \\
\hline His & 2.2 & & & \\
\hline Ileu & 4.7 & & & \\
\hline Leu & 6.0 & & & \\
\hline Lys & 9.7 & & & \\
\hline Met & 4.4 & & & \\
\hline Phe & 6.3 & & & \\
\hline Thr & 4.4 & & & \\
\hline $\operatorname{Trp}$ & 0.9 & & & \\
\hline Val & 4.7 & & & \\
\hline Ala & 1.9 & & & \\
\hline Asp & 1.9 & & & \\
\hline Glu & 18.9 & & & \\
\hline Gly & 12.6 & & & \\
\hline Pro & 1.9 & & & \\
\hline Cys & 1.9 & & & \\
\hline Ser & 1.9 & & & \\
\hline Tyr & 1.9 & & & \\
\hline $\mathrm{NaAc}$ & 8.2 & & & \\
\hline
\end{tabular}

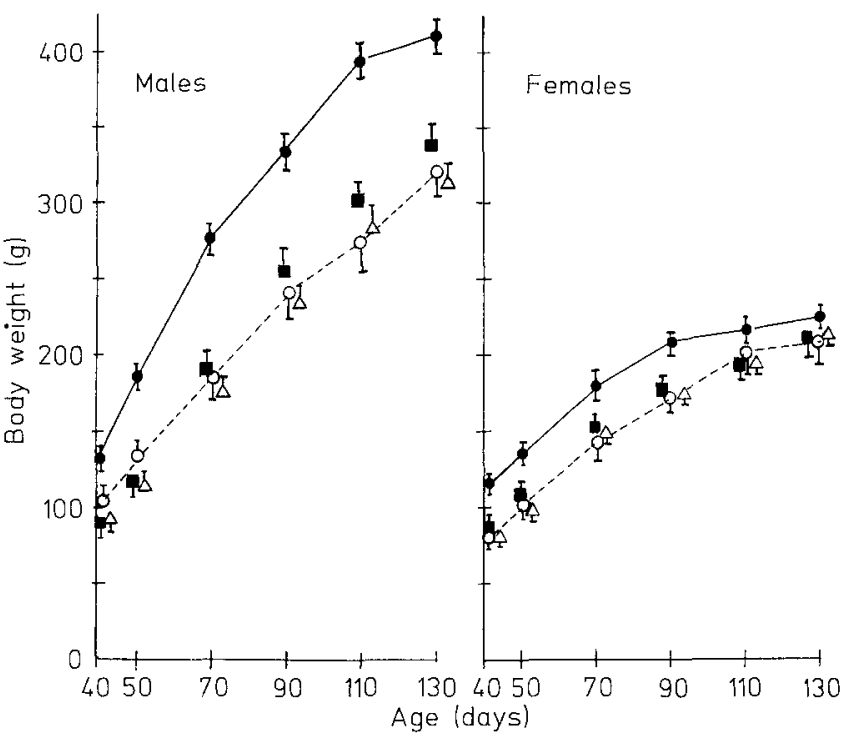

Fig. 1. Body weight versus age. Before the development of diabetes, the mean body weights of male and female rats fed the three semi-synthetic diets were not different between groups ( $p>0.05$ using the nonpaired t-test). The chow-fed rats were significantly heavier $(p<0.05)$ than those in the other groups for the duration of the experiment in the males but only until the age of 90 days in the females. The key and the number of animals in each group at the start and at the end of the experiment are: $\longrightarrow$; chow control (males 20 and 8; females 19 and 12). $\bigcirc-O$ group 1 (males 10 and 9 ; females 9 and 7 ). $\Delta$ group 2 (males 9 and 6; females 11 and 7). $\boldsymbol{a}$, group 3 (males 9 and 4; females 12 and 6 )

gliadin supplemented group (35\%) is less than expected although not significantly so $(2 p=0.42)$ whereas the incidence in the group on the unsupplemented semi-synthetic diet $(15 \%)$ was clearly lower $(2 p=0.028)$.

All diabetic animals showed a non-fasting blood glucose $>9.1 \mathrm{mmol} / \mathrm{l}($ mean $18.9 \mathrm{mmol} / \mathrm{l})$. Non-diabetic animals had a mean \pm SD blood glucose of $5.4 \pm$ $1.3 \mathrm{mmol} / \mathrm{l}$ at the end of the experiment.

Table 2. Incidence and age of onset of diabetes

\begin{tabular}{|c|c|c|c|c|c|c|}
\hline & \multicolumn{3}{|l|}{ Incidence } & \multicolumn{3}{|c|}{ Mean age at onset (days) ${ }^{c}$} \\
\hline & Observed & Expected $^{\mathrm{a}}$ & $2 p^{\mathrm{b}}$ & Total & Male & Female \\
\hline $\begin{array}{l}\text { Group } 1 \\
\quad \text { (semi-synthetic amino-acid diet) }\end{array}$ & $3 / 19$ & $9 / 19$ & 0.028 & $96.7 \pm 24.1$ & $\begin{array}{l}105 \\
(1 / 10)\end{array}$ & $\begin{array}{l}70 \\
(2 / 9)\end{array}$ \\
\hline $\begin{array}{l}\text { Group } 2 \\
\quad(1 \% \text { gliadin })\end{array}$ & $7 / 20$ & $10 / 20$ & NS & $87.8 \pm 15.2$ & $\begin{array}{l}113 \\
(3 / 9)\end{array}$ & $\begin{array}{l}80 \\
(4 / 11)\end{array}$ \\
\hline $\begin{array}{l}\text { Group } 3 \\
\quad \text { (1\% skim milk) }\end{array}$ & $11 / 21$ & $10 / 21$ & NS & $83.1 \pm 17.1$ & $\begin{array}{c}94 \\
(5 / 9)\end{array}$ & $\begin{array}{l}83 \\
(6 / 12)\end{array}$ \\
\hline Standard chow control & $19 / 39$ & $19 / 39$ & - & $85.1 \pm 15.1$ & $\begin{array}{c}85 \\
(12 / 20)\end{array}$ & $\begin{array}{l}86 \\
(7 / 19)\end{array}$ \\
\hline
\end{tabular}

${ }^{\mathrm{a}}$ The expected values were based on the current incidence of diabetes of approximately $50 \%$ in our partially inbred BB rat colony; ${ }^{b}$ Fisher's exact test, comparing experimental groups with chow-control group. $\mathrm{NS}=$ not significant; ${ }^{\mathrm{c}}$ ages expressed as mean $\pm \mathrm{SD} ;{ }^{\mathrm{d}}$ incidence in parentheses 
Histology of the pancreases of the diabetic animals showed the expected changes [1], while the islets of the non-diabetic rats were normal.

\section{Discussion}

The changes in incidence of diabetes among the experimental groups are unlikely to be due to the slow rate of body weight increase, since comparison of body weight between the three groups fed the semi-synthetic diets revealed non-significant differences when analysed by Student's t-test at the various ages throughout the study. The only exceptions were the female rats fed the milk supplemented diet versus the gliadin group at 50 days. Furthermore, all three groups achieved similar increases in body weight from age 40 to 130 days, between 180 and $208 \%$. The body weight of the chow-fed control male rats was significantly higher throughout the experiments when compared with the males fed the experimental diets, but this difference in the female rats vanished after the age of 100 days. Regardless of the different body weight patterns between chow- and semisynthetic diet fed groups, the important comparison in this study is the correlation of incidence of diabetes with the absence or addition of natural proteins to the basic amino-acid diet.

Accordingly, the presence of intact protein in the diet appears necessary for the full expression of the genetic susceptibility to develop diabetes in this colony of BB rats. Despite an approximately twofold addition of protein in the gliadin group compared with the milk group, the effect of the cereal protein was less than that of the animal protein, suggesting that certain amino-acids or combinations thereof, more common in the animal than in the vegetable protein, are the determinants. The unsupplemented diet is replete in essential amino-acids [2]. Speculation concerning the mechanism of this effect has no support from the present study, but an immunological or biochemical basis could be considered.

Some support for the hypothesis that diet may contribute to the pathogenesis of diabetes in children may be drawn from the varying incidence of insulin-dependent diabetes in different parts of the world, with the higher incidences being found in countries with a high protein intake as indicated above. While such differences might well be due to a variety of other environmental effectors, or even miscegenation, the experimental results cited above provide some rationale for speculating that increased dietary intake of protein may be involved in the pathogenesis of the disease in children.

Acknowledgements. We thank J.King, M.Lamptey, I.Sun and R. Abramovitch for assistance. Supported by Canadian Diabetes Association and the Health Life Sciences Division of Miles Laboratories, USA. Dr. R. B. Elliott was on sabbatical leave from the Institute of Child Health Research, University of Auckland, Auckland, New Zealand.

\section{References}

1. Marliss EB, Sima AAF, Nakhooda AF (1981) Spontaneous diabetes in the BB-Wistar rat. In: Martin JM, Ehrlich RM, Holland FJ (eds) Etiology and pathogenesis of insulin-dependent diabetes mellitus. Raven Press, New York, pp 251-274

2. Rogers QR, Harper AE (1965) Amino acids diets and maximal growth in the rat. J Nutrition $87: 267-273$.

Received: 5 May 1983

and in revised form: 29 December 1983

Dr. J.M. Martin

Research Institute

The Hospital for Sick Children

555 University Avenue

Toronto, Ontario

Canada M5G 1 X8 